\title{
Controlled Atmosphere Storage of 'Redcoat' Strawberry Fruit
}

\author{
Richard B. Smith \\ Horticultural Research Institute of Ontario, Vineland Station, Ont. LOR 2EO, Canada
}

Additional index words. bioyield point, carbon dioxide, oxygen, firmness enhancement, pectin, Fragaria x ananassa

\begin{abstract}
Strawberries (Fragaria x ananassa Duch.) Cv. Redcoat were stored at several temperatures and for various intervals in controlled atmospheres $(\mathrm{CA})$ containing $0 \%$ to $18 \% \mathrm{CO}_{2}$ and $15 \%$ to $21 \% \mathrm{0}_{2}$. Bioyield point forces recorded on the $\mathrm{CA}$-stored fresh fruit indicated that the addition of $\mathrm{CO}_{2}$ to the storage environment enhanced fruit firmness. Fruit kept under $15 \% \mathrm{CO}_{2}$ for 18 hours was $48 \%$ firmer than untreated samples were initially. Response to increasing $\mathrm{CO}_{2}$ concentrations was linear. There was no response to changing $\mathrm{0}_{2}$ concentrations. Maximum enhancement of firmness was achieved at a fruit temperature of $0 \mathrm{C}$; there was essentially no enhancement at 21C. In some instances, there was a moderate firmness enhancement as time in storage increased. Carbon dioxide acted to reduce the quantity of fruit lost due to rot. Fruit that was soft and bruised after harvest became drier and firmer in a $\mathrm{CO}_{2}$-enriched environment.
\end{abstract}

The 'Redcoat' strawberry, widely grown in Ontario, is soft and does not retain good quality during marketing. A means of retaining fruit quality and enhancing firmness would make the berries more acceptable to retailers and consumers. Harris and Harvey (1973) and Li and Kader (1989) reported that $\mathrm{CO}_{2}$ helps prevent softening in fresh fruit in storage. Investigations conducted in Poland (Lange et al., 1978; Ptocharski, 1982) and preliminary investigations conducted in this laboratory (R. B.S., unpublished data) indicated that $\mathrm{CO}_{2}$ actually will induce firming in strawberries, causing them to become firmer than they were at harvest.

The objectives of this investigation were to 1) test whether storage in $\mathrm{CO}_{2}=$ enriched atmospheres using various temperatures and exposure intervals enhances firmness of 'Redcoat' strawberry fruit and 2) determine whether any firmness enhancement is lost once the fruit is removed from the $\mathrm{CO}_{2}$ environment. Other quality characteristics were observed to determine whether the $\mathrm{CO}_{2}$ exposure caused any deleterious changes to the fruit.

\section{Materials and Methods}

'Redcoat' strawberries were harvested in the early morning from a commercial planting and transported to the laboratory within $1 \mathrm{~h}$. Containers of 400 to $450 \mathrm{~g}$ of fruit were randomized among the various treatments and forced-air cooled to treatment temperatures. Samples were kept for $1 \mathrm{~h}$ at the desired temperature to ensure equilibration and then sealed for storage in polyethylene units equipped with inlet-outlet ports (Smith and Reyes, 1988). Atmospheres were monitored with a Nova 305 portable $\mathrm{CO}_{2} / \mathrm{O}_{2}$ analyzer (Nova Analytical Systems, Hamilton, Ont., Canada) and adjusted with compressed $\mathrm{N}_{2}, \mathrm{O}_{2}$, and $\mathrm{CO}_{2}$. Zero percent $\mathrm{CO}_{2}$ was maintained with hydrated lime. In each trial, the treatments were replicated three times.

$\mathrm{CO}_{2}$ and $\mathrm{O}_{2}$ concentrations (Trial 1). Storage atmospheres contained $\mathrm{O} \%, 9 \%, 12 \%, 15 \%$, or $18 \% \mathrm{CO}_{2}$ in all combinations with $15 \%, 18 \%$, and $21 \% \mathrm{O}_{2}$. Storage was at 0C. Eight sub-

Received for publication 20 Aug. 1990. Accepted for publication 28 Oct. 1991. The author wishes to thank L.J. Skog and J. Nichols for technical assistance, Brian Allen (Univ. of Guelph) for statistical assistance. I acknowledge the monetary support from the Ontario Berry Growers' Assn., Louth Niagara Orchards, and the Agriculture and Food Research Fund. The cost of publishing this paper was defrayed in part by the payment of page charges. Under postal regulations, this paper therefore must be hereby marked advertisement solely to indicate this fact. samples from each replicate were stored under each atmospheric condition; four were removed from each unit after $18 \mathrm{~h}$ of exposure to the controlled atmosphere (CA) and four were removed after $110 \mathrm{~h}$. Two subsamples from each atmosphere/ storage time treatment combination were removed from the cold room just after removal from $\mathrm{CA}$, and two were held at $0 \mathrm{C}$ (post-CA storage) for $48 \mathrm{~h}$ and then removed. One of the samples was evaluated immediately upon removal from cold storage; the second was kept for $24 \mathrm{~h}$ at $20 \mathrm{C}$ and then evaluated (evaluation time).

The fruit from each treatment was first graded into categories of physical condition: good, soft, and decayed. A berry was considered soft if $\geq 25 \%$ of the surface area exhibited signs of excessive bruising (soft and wet). Since fruit temperature affects firmness (Blanpied et al., 1978; Bourne, 1982), a 15-berry sample of the good, unbruised fruit was kept in a $1 \mathrm{C}$ room for $1 \mathrm{~h}$ for temperature equilibration before conducting firmness determinations. Firmness, recorded on a 15-berry sample as the bioyield point force - the force required to initiate shearing (Voisey et al., 1972) (Ottawa Texture Measuring System, Canner's Machinery, Simcoe, Ont.) — was measured on the fruit shoulder through the skin using a $6.35-\mathrm{mm}$ flat tip probe.

Samples of $100 \mathrm{~g}$ of fruit from each treatment and replicate for berries kept $18 \mathrm{~h}$ in CA and $18 \mathrm{~h}$ plus $24 \mathrm{~h}$ at room temperature were frozen $(-30 \mathrm{C})$ for subsequent textural studies. Portions consisting of half berries of numerous fruits from one treatment were combined to give a broad-based representative sample. These samples were microwave-thawed (two defrost cycles of $1 \mathrm{~min}$ each) and evaluated using a Kramer shear cell adapted to the Ottawa Texture Measuring System (Voisey et al., 1972). Firmness was measured as a function of maximum force applied to shear the thawed sample.

The data from this trial were tested by means of a split plot analysis of variance (ANOVA) with the Statistical Analysis System (SAS) program package (SAS Institute, Cary, N.C.). The magnitude and precision of the experiment were such that the error mean square was very small. As a result, there were many interactions representing responses that were very small in magnitude ( $<5 \%$ change) and thus of little physiological importance and providing little information on elucidation of objectives. Therefore, the data were reanalyzed as if two separate experiments had been conducted. Only those factors significant relative to objective 1 ( $\mathrm{CO}_{2}$ effects on berry firmness) were considered. Factors in the analysis included CA storage time, $\mathrm{CO}_{2}$, and $\mathrm{O}_{2}$ for $0 \mathrm{~h}$ post-CA storage and $0 \mathrm{~h}$ evaluation time. 
Those factors having direct bearing on the second objective (firmness changes after removal from CA) were post-CA storage time and evaluation time. Since time in CA storage could have an effect, this factor was also included in the analysis. Data for this analysis were selected to represent CA storage conditions of $15 \% \mathrm{CO}_{2}$ and $18 \% \mathrm{O}_{2}$, the atmosphere used in Trial 3 .

$\mathrm{CO}_{2}$ concentration and temperature (Trial 2). The samples were cooled to a pulp temperature of $21,14,7$, or $0.5 \mathrm{C}$ and then placed in treatment rooms at $21,14,7$, or $0 \mathrm{C}$ for $1 \mathrm{~h}$. The samples were then sealed in ployethylene storage units. We used $0 \%, 6 \%, 12 \%$, or $18 \% \mathrm{CO}_{2}$ at each storage temperature. Oxygen was maintained at $15 \%$ for all levels of $\mathrm{CO}_{2}$. Samples for analysis were removed after exposure to $\mathrm{CO}_{2}$ for $4,9,21$, or $30 \mathrm{~h}$.

Bioyieid force measurements (15-berry sample) were recorded with the skin intact and on internal flesh after removal of a slice of skin. Bioyields were determined with skin removed for samples from all treatment combinations, except $9 \mathrm{~h}$. To allow for temperature equilibration for firmness measurements, all fruit was placed in a $0 \mathrm{C}$ cold room for $2 \mathrm{~h}$ after removal from the respective cold rooms. A 100-g sample composed of portions of numerous berries that had been decapped, washed, and blotted dry, was fast-frozen ( - 30C) and subsequently analyzed for ammonium oxalate-soluble and water-soluble pectins by methods of the International Federation of Fruit Juice Producers (1964). Sample preparation for pectin analysis consisted of intermittent microwave heating (with occasional stirring for uniform heating) of the sample to $80 \mathrm{C}$ to. deactivate enzymes, cooling to 20C, addition of water to correct for moisture loss, and blending for $1 \mathrm{~min}$ (Osterizer Galaxie Six).

Degree of precooking (Trial 3). The berries were precooled to $0.5,2,4,6$, or $8 \mathrm{C}$ and kept for $1 \mathrm{~h}$ at $0,2,4,6$, or $8 \mathrm{C}$ before being placed in polyethylene storage units. The atmosphere in all units was adjusted to $15 \% \mathrm{CO}_{2}$ and $18.5 \% \mathrm{O}_{2}$. The fruit was evaluated after $\mathrm{O}, 2,4,8,22$, or $44 \mathrm{~h}$ in the CA atmosphere.

Tests for the bioyield point (15 berries, skin intact) were conducted as noted in Trial 1. Firmness (Voisey et al., 1972) (the prebioyield point slope) was recorded from the force-distance curve for bioyield points. Also, the energy (Joules) required to shear 200-g samples of treated fruit, frozen to $-30 \mathrm{C}$ and then thawed, was determined using a Kramer shear cell adapted to the Ottawa Texture Measuring System (Voisey et al., 1972). The samples had been thawed in a microwave oven (defrost cycle for 3 rein).

Data were tested with a split plot ANOVA with the SAS program package. Where applicable, regression analyses were conducted or means were compared using least significant difference. When statistical analysis indicated that a common intercept was present, the regressions were forced through that intercept. The quadratic was fitted where a curvilinear response was indicated. When regressions were not significantly different, a common regression was fitted. Interactions and higher order effects that were not significant were incorporated into the error term. Partial $R^{2}$ were calculated from the ratio (SSm $-\mathrm{SSr}) \div(\mathrm{SSm}+\mathrm{SSe}-\mathrm{SSr})$ (where $\mathrm{SSm}=$ model sum of squares, $\mathrm{SSr}=$ rep sum of squares, and $\mathrm{SSe}=$ error sum of squares). In Trial 1, initial samples were not evaluated for all possible levels of each factor, only representative samples for each replicate were tested. Thus, these means could not be included as a factor in the ANOVA. Comparison of initial means to the treatment means of stored samples was done by $t$ test; no such comparisons were made among stored sample means.

\section{Results}

Fruit exposed to $15 \% \mathrm{C}_{2}$ for 18 or $110 \mathrm{~h}$ were firmer than the initial samples (Table 1). As the concentration of $\mathrm{CO}_{2}$ in the storage atmosphere increased, the fruit became significantly firmer and quantity of decayed and soft fruit decreased (Table 1). The response to increasing concentrations of $\mathrm{CO}_{2}$ was linear (Table 1) for firmness, decay, and soft fruit. Based on regression equations, as storage atmosphere $\mathrm{CO}_{2}$ increased from $0 \%$ to $18 \%$, firmness increased by $29 \%$, decay decreased by $49 \%$, and the portion of soft fruit decreased by $42 \%$. Fruit in CA storage for $110 \mathrm{~h}$ compared with $18 \mathrm{~h}$ was firmer, had more decayed but less soft fruit. The concentration of $\mathrm{O}_{2}$ had no effect on firmness or quantity of soft or decayed fruit.

When CA storage time was included as a factor with evaluation time and post-CA storage time, CA storage time had no effect on firmness or quantity of decayed fruit (Table 2). After $24 \mathrm{~h}$ at $20 \mathrm{C}$ compared with $0 \mathrm{~h}$, fruit had become firmer and the quantity of decay had increased during this interval. Post-CA storage time at $\mathrm{OC}$ had no effect on firmness or quantity of soft fruit; however, there was more decay in the fruit kept for $48 \mathrm{~h}$ than in fruit kept for $0 \mathrm{~h}$. An interaction between CA storage time and evaluation time (Table 3) indicated that there was less soft fruit in samples evaluated immediately after 110 $\mathrm{h}$ of storage than in those evaluated after $24 \mathrm{~h}$ at room temperature or in those stored in CA for $18 \mathrm{~h}$.

Table 1. Comparison of $0 \mathrm{~h}$ untreated samples (initials) with the average firmness of stored strawberries and effects of $\mathrm{CO}_{2}$ and $\mathrm{O}_{2}$ concentration in the storage atmosphere and duration of exposure to controlled atmosphere on firmness (bioyield point force) and quantity of soft and decayed fruit at $0 \mathrm{~h}$ post-CA cold storage and evaluation after $0 \mathrm{~h}$ at $20 \mathrm{C}$. (Trial 1 ).

\begin{tabular}{lccc}
\hline Factor & ${\text { Firmness }(\mathrm{N})^{\mathrm{z}}}^{\mathrm{D}}$ & $\begin{array}{c}\text { Decayed fruit } \\
(\% \text { by wt) }\end{array}$ & $\begin{array}{c}\text { Soft fruit } \\
(\% \text { by wt })\end{array}$ \\
\hline Initial $^{\mathrm{y}}$ & 2.7 & $\mathrm{~N} / \mathrm{A}$ & $\mathrm{N} / \mathrm{A}$ \\
Mean for stored samples & 4.5 & N/A & N/A \\
CA storage (h) (S) ${ }^{\mathrm{w}, \mathrm{x}}$ & & & \\
18 & $3.71 \mathrm{a}$ & $0.79 \mathrm{a}$ & $3.01 \mathrm{a}$ \\
110 & $3.97 \mathrm{~b}$ & $1.41 \mathrm{~b}$ & $1.28 \mathrm{~b}$ \\
$\mathrm{CO}_{2}$ concn $^{\mathrm{w}, \mathrm{v}}(\%)$ & & & \\
0 & 3.25 & 1.72 & 3.11 \\
9 & 3.74 & 1.03 & 2.00 \\
12 & 3.94 & 1.00 & 1.99 \\
15 & 4.15 & 0.88 & 1.83 \\
18 & 4.18 & 0.87 & 1.80 \\
\hline
\end{tabular}

${ }^{x}$ Means presented for firmness are for the original data, ANOVA conducted using $\log \mathrm{N}$. Bioyield force $=$ force required to initiate shearing of flesh using a flat-tip probe.

${ }^{y}$ Comparison by $t$ test $(P=0.05)$ of initial sample firmness to the mean firmness of stored samples, the latter stored under $15 \% \mathrm{CO}_{2}$ plus $18 \% \mathrm{O}_{2}$ for 18 or $110 \mathrm{~h}$ and evaluated just after removal from CA or after $48 \mathrm{~h}$ at room temperature. No significant difference between means within stored samples.

xMean separation by ANOVA $(P=0.05)$. Number of observations per mean for $\mathrm{S}=45, \mathrm{O}_{2}=30$, and $\mathrm{CO}_{2}=18$; each observation mean of 15 berries.

wNonsignificant interactions and higher-order effects incorporated into the error term.

vPartial $R^{2}$ and linear regressions for significant main effects, no interactions present.

Relationship $R^{2}$

Firmness $(\mathrm{N})=3.26+0.055\left[\mathrm{CO}_{2}\right] \quad 0.72$

Decayed $(\%)=1.62-0.049\left[\mathrm{CO}_{2}\right] \quad 0.59$

Soft $(\%)=2.95-0.074\left[\mathrm{CO}_{2}\right] \quad 0.31$ 
Table 2. Effect of CA storage time, post-CA cold storage, and evaluation time on firmness (bioyield point force) and quantity of soft and decayed fruit stored with $15 \% \mathrm{CO}_{2}$ plus $18 \% \mathrm{O}_{2}$ (Trial 1 ).

\begin{tabular}{|c|c|c|c|}
\hline Factor & Firmness $(N)^{z, y}$ & $\begin{array}{l}\text { Decayed fruit } \\
(\% \text { by wt })^{\mathrm{y}}\end{array}$ & $\begin{array}{l}\text { Soft fruit } \\
(\% \text { by wt })^{y}\end{array}$ \\
\hline \multicolumn{4}{|c|}{ CA storage (h) } \\
\hline 18 & $4.48 \mathrm{a}$ & $1.69 \mathrm{a}$ & Int. ${ }^{x}$ \\
\hline 110 & $4.55 \mathrm{a}$ & $1.93 \mathrm{a}$ & Int. \\
\hline \multicolumn{4}{|c|}{ Evaluation (h) } \\
\hline 0 & $4.38 \mathrm{a}$ & $0.95 \mathrm{a}$ & Int. ${ }^{x}$ \\
\hline 24 & $4.67 \mathrm{~b}$ & $2.68 \mathrm{~b}$ & Int. \\
\hline \multicolumn{4}{|c|}{$\begin{array}{l}\text { Post-CA storage } \\
\text { at } 0 \mathrm{C}(\mathrm{h})\end{array}$} \\
\hline 0 & $4.40 \mathrm{a}$ & $1.44 \mathrm{a}$ & $1.41 \mathrm{a}$ \\
\hline 48 & $4.63 \mathrm{a}$ & $2.18 \mathrm{~b}$ & $1.20 \mathrm{a}$ \\
\hline \multicolumn{4}{|c|}{$\begin{array}{l}\text { zMeans presented for firmness are for the original data, ANOVA con- } \\
\text { ducted using } \log N \text {. } \\
\text { yMean separation with factors by ANOVA }(P=0.05) \text {. Number o } \\
\text { observations per mean }=12 \text {, each observation an average of } 15 \text { ber } \\
\text { ries. } \\
\text { xInteraction, CA storage time } \times \text { evaluation time significant; see Table } \\
3 \text {. }\end{array}$} \\
\hline \multicolumn{4}{|c|}{$\begin{array}{l}\text { Table 3. Interactive effects of time in controlled-atmosphere (CA) } \\
\text { storage and evaluation time on percentage of soft fruit (Trial 1). }\end{array}$} \\
\hline \multicolumn{2}{|l|}{$\begin{array}{l}\text { CA storage } \\
\text { (h) }\end{array}$} & & $\begin{array}{l}\text { Soft fruit } \\
\text { (\% by wt) }\end{array}$ \\
\hline 18 & & & $\begin{array}{l}1.65 \mathrm{a} \\
1.23 \mathrm{ab}\end{array}$ \\
\hline \multirow[t]{2}{*}{110} & & & $1.62 \mathrm{~b}$ \\
\hline & & & $1.72 \mathrm{a}$ \\
\hline
\end{tabular}

${ }^{2}$ Means separated by LSD $(0.94)(P=0.05)$. Number of observations per mean $=6$, each observation, an average of 15 berries.

e maximum force required to shear frozen and subsequently thawed samples was not affected by storage factors.

When firmness was measured with the skin intact or removed, fruit in CA storage became firmer as time in CA storage increased (Table 4). The response was linear. For fruit with skin removed there was a linear increase in firmness as concentration of $\mathrm{CO}_{2}$ increased. However, there was a linear decrease as temperature of fruit increased. With the skin intact, $\mathrm{CO}_{2}$ concentration and fruit temperature interacted to affect firmness (Table $5)$. As temperature of the fruit increased, the firming effect of the $\mathrm{CO}_{2}$ was dimished. The fruit stored under $12 \%$ and $18 \%$ $\mathrm{CO}_{2}$ were firmer than fruit stored under $6 \% \mathrm{CO}_{2}$ (equations significantly different from each other), while the fruit under $0 \% \mathrm{CO}_{2}$ was the softest.

There was a linear increase in the quantity of ammonium oxalate- and water-soluble pectins, the former in response to $\mathrm{CA}$ storage time and the latter in response to storage temperature (Table 4). Concentration of $\mathrm{CO}_{2}$ had no effect on either fraction.

In Trial 3, firmness (bioyield point force and prebioyield point slope) was affected by an interaction between CA storage time and temperature of the fruit (Table 6). As temperature of fruit and CA storage time increased there was a curvilinear increase in firmness (bioyield force) at 0 and $2 \mathrm{C}$ and a linear response at 4,6 , and $8 \mathrm{C}$. Whenever firmness was measured as a prebioyield slope response on the force-distance curve, a curvilinear response was present for temperatures from 0 to $4 \mathrm{C}$ and no significant response at 6 and $8 \mathrm{C}$ (zero slope). In this trial storage factors had no effect on decay (Table 7). An interaction between time and temperature affected quantity of soft fruit, but the
Table 4. Effects of $\mathrm{CO}_{2}$ concentration in the storage atmosphere, time in CA storage, and temperature of fruit during exposure on firmness (bioyield point force) of strawberries (measured with the skin intact and removed) and quantity of ammonium oxalate- and water-soluble pectins in strawberry fruit (Trial 2).

\begin{tabular}{|c|c|c|c|c|}
\hline \multirow[b]{3}{*}{ Factor } & \multirow{2}{*}{\multicolumn{2}{|c|}{$\frac{\text { Firmness }(\mathrm{N})^{\mathrm{z}}}{\text { Skin }}$}} & \multicolumn{2}{|c|}{$\begin{array}{c}\text { Pectin fraction } \\
\text { (mg galacturonic acid/kg fruit) }\end{array}$} \\
\hline & & & \multirow[b]{2}{*}{ Water-soluble ${ }^{y}$} & \multirow{2}{*}{$\begin{array}{c}\text { Ammonium } \\
\text { oxalatex }\end{array}$} \\
\hline & Intact & Removed & & \\
\hline \multicolumn{5}{|c|}{$\mathrm{CO}_{2}$ concn $\left(\% \mathrm{CO}_{2}\right)^{\mathrm{v}, \mathrm{w}}$} \\
\hline 0 & Int." & 1.74 & 2340 & 3240 \\
\hline 6 & Int. & 1.84 & 2260 & 3250 \\
\hline 12 & Int. & 1.96 & 2220 & 3170 \\
\hline 18 & Int. & 2.10 & 2210 & 3250 \\
\hline \multicolumn{5}{|c|}{$\operatorname{Temp}\left(\mathrm{T} ;{ }^{\circ} \mathrm{C}\right)^{\mathrm{v}, \mathrm{w}}$} \\
\hline 0 & Int. & 2.35 & 2080 & 3180 \\
\hline 7 & Int. & 1.89 & 2290 & 3260 \\
\hline 14 & Int. & 1.77 & 2360 & 3320 \\
\hline 21 & Int. & 1.67 & 2310 & 3250 \\
\hline \multicolumn{5}{|c|}{ CA storage $(S ; h)^{v, w}$} \\
\hline 0 & 2.46 & 1.68 & 2270 & 2940 \\
\hline 4 & 2.51 & 1.76 & 2190 & 3100 \\
\hline 9 & 2.63 & -- & --- & --- \\
\hline 21 & 2.81 & 2.02 & 2280 & 3340 \\
\hline 30 & 2.90 & 1.94 & 2310 & 3250 \\
\hline
\end{tabular}

${ }^{\mathrm{z}}$ Firmness (N) measured at the bioyield point. Means presented are for original data, ANOVA conducted using log N. Nonsignificant higher order effects incorporated into the error term.

${ }^{y} \mathrm{CO}_{2}$ and $\mathrm{CA}$ storage time had no effect on water-soluble pectin by ANOVA $(P=0.05)$.

${ }^{x} \mathrm{CO}_{2}$ and temperature had no effect on ammonium oxalate soluble pectin content by ANOVA $(P=0.05)$.

"Number of observations per mean for $\mathrm{CO}_{2}=60$, for $\mathrm{T}=60$, and for $S=40$; each observation an average of 15 berries.

vartial $R^{2}$ and linear regressions for significant main effects.

Factor Relationship $R^{2}$

S Firmness (N)

$($ skin intact $)=2.47+0.05[$ Time]

0.92

$\mathrm{CO}_{2} \quad$ Firmness (N)

(skin removed) $=1.73+0.02\left[\mathrm{CO}_{2}\right]$

0.89

$\mathrm{S} \quad$ Firmness (N)

(skin removed) $=1.76+0.01[$ Time $]$

T Firmness (N)

(skin removed) $=2.24-0.03[$ Temp]

T Water soluble

pectin $\left(\mathrm{mg} \cdot \mathrm{kg}^{-1}\right)=2141.0+11.0$ [Temp]

0.66

$\mathrm{S}$ Ammonium oxalate-

soluble pectin

$\left(\mathrm{mg} \cdot \mathrm{kg}^{-1}\right)$

$=3099.7+7.03$ [Time]

0.35

unteractions present in this data, $\mathrm{CO}_{2} \times \mathrm{T}$ interaction data in Table 5.

changes were very minor and of little importance physiologically or practically. (Thus, other than main effect means, statistical data are not presented for quantity soft in Trial 3.) The firmness of fruit stored in CA, then frozen and then thawed, decreased and then increased as CA storage time increased (Table 7).

\section{Discussion}

Strawberries stored in $\mathrm{CO}_{2}$-enriched atmospheres for intervals Up to 5 days were firmer than the fruit was initially. Firmness was influenced by concentration of $\mathrm{CO}_{2}$, duration of CA storage, and temperature of the fruit. Harris and Harvey (1973) and $\mathrm{Li}$ and Kader (1989) reported that $\mathrm{CO}_{2}$ maintained berry firrn- 
Table 5. Effects of concentration of $\mathrm{CO}_{2}$ in the storage atmosphere and temperature of fruit during exposure on firmness (bioyield point force) of strawberries measured with the skin intact.

\begin{tabular}{|c|c|c|c|c|}
\hline \multirow{3}{*}{$\begin{array}{l}\mathrm{CO}_{2} \\
(\%)\end{array}$} & \multicolumn{4}{|c|}{ Firmness $(\mathrm{N})^{\mathrm{z}, \mathrm{y}}$} \\
\hline & \multicolumn{4}{|c|}{ Temp $\left({ }^{\circ} \mathrm{C}\right)$} \\
\hline & 0 & 7 & 14 & 21 \\
\hline 0 & 2.54 & 2.39 & 2.47 & 2.18 \\
\hline 6 & 3.18 & 2.53 & 2.61 & 2.39 \\
\hline 12 & 3.67 & 2.86 & 2.60 & 2.50 \\
\hline 18 & 3.72 & 2.86 & 2.81 & 2.50 \\
\hline
\end{tabular}

${ }^{\text {zTirmness }(\mathrm{N}) \text { measured at the bioyield point. Means presented are for }}$ the original data, ANOVA conducted using $\log \mathrm{N}$. Nonsignificant higherorder effects incorporated into the error term. Number of observations per mean $=15$, each observation an average of 15 berries.

ypartial $R^{2}$ and linear regressions of temperature on $\mathrm{CO}_{2}$. No significant difference in regressions for $12 \%$ and $18 \% \mathrm{CO}_{2}$; thus, one equation is used to describe these responses.

\begin{tabular}{llc} 
Factor & Relationship & $R^{2}$ \\
\hline $\mathrm{CO}_{2}(0 \%) \times \mathrm{T}$ & Firmness $(\mathrm{N})=$ & 0.68 \\
$\mathrm{CO}_{2}(6 \%) \times \mathrm{T}$ & $2.56-0.015$ [Temp] & \\
$\mathrm{CO}_{2}(12 \%$ and & Firmess $(\mathrm{N})=$ \\
$18 \%) \times \mathrm{T}$ & $3.04-0.034[$ Temp] \\
& $3.53-0.054[$ Temp]
\end{tabular}

ness, but Ptocharski (1982) reported that $\mathrm{CO}_{2}$ actually enhanced firmness. Research reported here indicated that 'Redcoat' berries kept at 0C under $15 \% \mathrm{CO}_{2}$ for $18 \mathrm{~h}$ were $48 \%$ firmer than samples were initially $[(4.0-2.7)$ x $100 \div 2.7=48 \%]$. The fact that berries did not soften during 3 days after removal from CA storage is of interest physiologically and of importance commercially.

The response to $\mathrm{CO}_{2}$ decreased as temperatures increased (Table 5; Trial 2). From the regression equations, fruit exposed to $18 \% \mathrm{CO}_{2}$ at $6 \mathrm{C}$ would have a firmness of $3.18 \mathrm{~N}$ compared with initial sample firmness of $2.46 \mathrm{~N}$. The difference would represent a $26 \%$ firmness enhancement, similar to the $20 \%$ to $25 \%$ firmness enhancement recorded at $6 \mathrm{C}$ by Ptocharski (1982) with 'Senga Sengana' berries. In Trial 2, fruit at $0 \mathrm{C}$ in $18 \%$ $\mathrm{CO}_{2}$ was $44 \%$ firmer than the initial untreated sample. At 0 to $2 \mathrm{C}$, much of the firming appeared to occur within $24 \mathrm{~h}$ of exposure to $\mathrm{CO}_{2}$. At 4 to $8 \mathrm{C}$, berries firmed more slowly, but after $44 \mathrm{~h}$ an essentially equal response was attained. At $14 \mathrm{C}$ (Table 5) the response was minimal and slow and at $21 \mathrm{C}$ essentially nil. Considering that higher temperatures nullify the effect of $\mathrm{CO}_{2}$ on firming berries, fruit in $\mathrm{CA}$ should be at or near $0 \mathrm{C}$ to realize the full enhancing potential of the $\mathrm{CO}_{2}$.

The effect of CA storage time on firmness was inconclusive. In Trial 1, in one instance, there was a statistically significant but minor enhancement (Table 1) and a nonsignificant effect in another (Table 2). This inconsistency in the same trial could be due to interactions or could reflect the fact that time in CA is only marginally significant. In Trial 2 , there was a moderate enhancement. attributable to time in CA. This increase paralleled an increase in pectin in the ammonium oxalate soluble fraction that possibly could account for the firmness enhancement associated with time. Moisture loss, minimal inside sealed, or indirectly cooled polyethylene storage units could have caused some external drying and firming but should not have had an internal effect where there was enhanced firmness attributable to CA storage time. Thus, the firmness enhancement associated with time was probably not due to moisture loss.
Table 6. Interactive effects of $\mathrm{CA}\left(15 \% \mathrm{CO}_{2}, 18.5 \% \mathrm{O}_{2}\right)$ storage time and temperature of storage on firmness of strawberries as measured by changes in bioyield point force and prebioyield point slope (Trial 3).

\begin{tabular}{ccccccc}
\hline \hline \multirow{7}{*}{$\begin{array}{c}\text { Temp }(\mathrm{T}) \\
\left({ }^{\circ} \mathrm{C}\right)\end{array}$} & 0 & 2 & 4 & 8 & 22 & 44 \\
\cline { 2 - 6 } & \multicolumn{6}{c}{ Firmness, bioyield point force $(\mathrm{N})^{\mathrm{z}, \mathrm{y}}$} \\
0 & 2.23 & 2.55 & 2.85 & 3.06 & 3.29 & 3.25 \\
2 & 2.33 & 2.37 & 2.61 & 3.07 & 3.05 & 3.23 \\
4 & 2.29 & 2.36 & 2.57 & 2.63 & 3.03 & 3.38 \\
6 & 2.23 & 2.38 & 2.59 & 2.51 & 2.85 & 3.08 \\
8 & 2.20 & 2.48 & 2.40 & 2.56 & 2.77 & 3.10 \\
\multicolumn{7}{c}{ Firmness, } \\
0 & 0.200 & 0.220 & 0.250 & 0.270 & 0.273 & 0.250 \\
2 & 0.213 & 0.233 & 0.240 & 0.267 & 0.260 & 0.263 \\
4 & 0.200 & 0.207 & 0.240 & 0.250 & 0.250 & 0.260 \\
6 & 0.197 & 0.217 & 0.230 & 0.217 & 0.240 & 0.247 \\
8 & 0.197 & 0.217 & 0.227 & 0.237 & 0.223 & 0.257 \\
\hline
\end{tabular}

${ }^{7}$ Means presented for firmness are for original data. ANOVA conducted using $\log \mathrm{N}$. Nonsignificant higher-order effects incorporated into the error term. Number of observations per mean $=3$, each observation an average for 15 berries.

y Partial $R^{2}$ and regression equations of time (linear and quadratic) on temperature (linear). No significant differences in regressions for 0 and $2 \mathrm{C}$ or 4,6 , and $8 \mathrm{C}$; thus, one equation used to describe response for 0 and $2 \mathrm{C}$ (quadratic) and one for 4, 6, and $8 \mathrm{C}$ (linear).

\begin{tabular}{lcc} 
Factor & Relationship & $R^{2}$ \\
\hline $\mathrm{S}(\mathrm{L}) \times \mathrm{T}(\mathrm{Q})(0$ and $2 \mathrm{C})$ & Firmness(N) $=2.40+$ & 0.82 \\
$\mathrm{~S}(\mathrm{~L}) \times \mathrm{T}(\mathrm{L})(4,6$, and $8 \mathrm{C})$ & $0.064[\mathrm{Temp}]+0.001[\mathrm{Temp}]^{2}$ & \\
& Firmness $(\mathrm{N})=2.40+$ & $0.34[\mathrm{Temp}]$
\end{tabular}

xPartial $R^{2}$ and regression equation of time (quadratic) on temperature (linear). No significant differences in regressions for 0,2 , and $4 C$; thus, one equation to describe response, slopes at 6 and $8 \mathrm{C}$ not significantly different from zero; thus, equations not presented.

\begin{tabular}{lcc} 
Factor & Relationship & $R^{2}$ \\
\hline $\mathrm{S}(\mathrm{L}) \times \mathrm{T}(\mathrm{Q})(0,2$, and $4 \mathrm{C})$ & Firmness $\left(\right.$ Slope, $\left.\mathrm{N} \cdot \mathrm{mm}^{-1}\right)=$ & 0.69 \\
& $0.216+0.0043[\mathrm{Temp}]-$ & \\
& $0.00008[\mathrm{Temp}]^{2}$
\end{tabular}

The prebioyield point slope measures resistance to deformation (Voisey et al., 1972). Since firm fruit deforms less than soft fruit when a given force is applied, the firmer the berry the steeper the prebioyield point slope. Prebioyield point slope data support bioyield firmness data trends in that time in CA and temperature of fruit interacted to affect firmness of fruit in CA.

Firmness measurements on the flesh (skin removed) revealed that internal flesh had also firmed as a result of $\mathrm{CO}_{2}$ exposure. Thus, the firming effect of $\mathrm{CO}_{2}$ was not a skin toughening phenomenon that might occur with minor dehydration.

Increased resistance to deformation presumably might be caused by changes in turgor or in pectin type or quantity. These factors also may affect bioyield firmness. Turgor is normally a moisture balance variable presumably not affected by $\mathrm{CO}_{2}$. Ptocharski (1982) showed that there are changes in pectin composition in strawberries subjected to $\mathrm{CO}_{2}$ and attributed firmness changes to these pectic changes. He also reported an increase in the quantity of pectin in the ammonium oxalate-soluble fraction and a decrease in the water-soluble fraction. Analysis of strawberries in our laboratory did not reveal any changes in the ammonium oxalate- or water-soluble fraction that could be attributed to the $\mathrm{CO}_{2}$ treatments. There was a significant increase in the am- 
Table 7. Effect of CA $\left(15 \% \mathrm{CO}_{2}, 18.5 \% \mathrm{O}_{2}\right)$ storage time and temperature of fruit in storage on percent decay, percent soft, and the energy required to shear thawed fruit (Trial 3).

\begin{tabular}{|c|c|c|c|c|}
\hline \multicolumn{2}{|l|}{$\begin{array}{l}\text { Duration and } \\
\text { temp of storage }\end{array}$} & \multirow{2}{*}{$\begin{array}{c}\begin{array}{c}\text { Decay } \\
(\%)^{2}\end{array} \\
0.30\end{array}$} & \multirow{2}{*}{$\begin{array}{c}\begin{array}{c}\text { Soft } \\
(\%)^{y}\end{array} \\
0.39\end{array}$} & \multirow{2}{*}{$\begin{array}{c}\begin{array}{c}\text { Shear } \\
\text { energy }(J)^{2, x}\end{array} \\
7.17\end{array}$} \\
\hline Time (h) (S)w & 0 & & & \\
\hline & 2 & 0.10 & 0.67 & 6.41 \\
\hline & 4 & 0.09 & 0.80 & 5.30 \\
\hline & 8 & 0.12 & 0.73 & 5.20 \\
\hline & 22 & 0.05 & 0.51 & 5.64 \\
\hline & 44 & 0.10 & 0.87 & 5.66 \\
\hline \multirow{5}{*}{$\operatorname{Temp}\left({ }^{\circ} \mathrm{C}\right)(\mathrm{T})^{\mathrm{w}}$} & 0 & 0.22 & 0.70 & 5.30 \\
\hline & 2 & 0.07 & 0.62 & 5.38 \\
\hline & 4 & 0.03 & 0.49 & 6.35 \\
\hline & 6 & 0.19 & 0.50 & 6.33 \\
\hline & 8 & 0.12 & 1.00 & 6.17 \\
\hline
\end{tabular}

${ }^{2} \mathrm{CA}$ storage time had no significant effect on quantity of decay; temperature of fruit had no effect on quantity of decay or shear energy. ${ }^{y}$ ANOVA indicated presence of a significant $S \times T$ interaction. However, the magnitude of the changes was small and would be of little physiological or commercial significance, thus, $S \times T$ regression data not presented.

xartial $R^{2}$ and regression equations for time (quadratic) for shear energy.

Factor

Relationship

$R^{2}$

S Shear energy $(J)=6.46-0.108[$ Time $]+\quad 0.15$ $0.0021[\text { Time }]^{2}$

wumber of observations per mean for $S=15$ and $T=18$, each observation an average of 15 berries.

monium oxalate soluble pectin fraction that was attributable to the time in CA storage and a significant increase in the watersoluble fraction, attributable to temperature of fruit. The berries used in our investigation possibly were not sufficiently well matched to detect changes. However, considering the complete absence of a relationship between the two pectin fractions and $\mathrm{CO}_{2}(P=0.90$ for ammonium oxalate- and 0.38 for watersoluble fraction) and the significant increase in firmness as $\mathrm{CO}_{2}$ concentration increased, it appears that with 'Redcoat' other compositional factors may be a factor. When exposed to $\mathrm{CO}_{2}$, strawberries may become firmer by the same mechanism or biochemical change that induces firming in tart cherries after they have been bruised (Matz, 1962). As with cherries, where the change is more pronounced at $1 \mathrm{C}$ than at temperatures $>10 \mathrm{C}$, firming in strawberries was more pronounced at $0 \mathrm{C}$ than at 14 or $21 \mathrm{C}$

In Trial 1 there was no indication that storage factors had any effect on the firmness of berries that had been frozen and thawed. Generally, firmer fresh fruit resulted in firmer frozen thawed fruit. The texture of frozen thawed fruit cannot be improved by treating fresh fruit with $\mathrm{CO}_{2}$ before freezing.

The quantity of decayed fruit increased with $\mathrm{CA}$ storage time but decreased as concentration of $\mathrm{CO}_{2}$ in the storage atmosphere increased. This response to $\mathrm{CO}_{2}$ has been recorded previously (Couey and Wells, 1970; Harris and Harvey, 1973) and has been attributed to $\mathrm{CO}_{2}$ suppressing fungal growth.

In Trial 1, the quantity of bruised fruit graded unacceptably soft decreased as time in CA storage increased and as $\mathrm{CO}$ concentration increased. This phenomenon appeared to be due to a drying and presumably firming of wounded tissue. This drying and firming effect of $\mathrm{CO}_{2}$ would provide further justification for using $\mathrm{CO}_{2}$ in storing and shipping strawberries.

There was no indication that the $\mathrm{CO}_{2}$ caused any undesirable changes in quality of the fruit. Organoleptic data (R.B.S., unpublished) "showed that the $\mathrm{CO}_{2}$ did not adversely affect fruit quality. The positive response of 'Redcoat' fruit to $\mathrm{CO}_{2}$ and possibly that of other soft-fruited cultivars, justifies the recommendation that such fruit be stored in a $\mathrm{CO}_{2}$-enriched atmosphere for several hours after harvest or be shipped under $\mathrm{CO}_{2}$-enriched atmospheres.

\section{Literature Cited}

Blanpied, G. D., W.J. Bramlage, D.H. Dewey, R.L. Labelle, L.M. Massey, G.E. Mattus, W.C. Stiles, and A.E. Watada. 1978. A standardized method for collecting apple pressure test data. N.Y. Food and Life Sci. Bul. 74.

Boume, M.C. 1982. Effect of temperature on firmness of raw fruits and vegetables. J. Food Sci. 47:440-444.

Couey, H.M. and J.M. Wells. 1970. Low-oxygen or high carbon dioxide atmospheres to control postharvest decay in strawberries. Phytopathology 60:47-49.

Harris, C.M. and J.M. Harvey. 1973. Quality and decay of strawberries stored in $\mathrm{CO}_{2}$-enriched atmospheres. Plant Dis. Rptr. 57:44-46.

International Federation of Fruit Juice Producers. 1964. Determination of pectin. Analyses. no. 26. Zug, Switzerland. p. 1-6.

Lange, E., W. Ptocharski, and W. Lenartowicz. 1978. Strawberriesquality of fruits, their storage life and suitability for processingPart I. Fruit Sci. Rpt. 5(2):39-46.

Li, C. and A.A. Kader. 1989. Residual effects of controlled atmospheres on postharvest physiology and quality of strawberries. J. Amer. Soc. Hort. Sci. 114(4):629-534.

Matz, S.A. 1962. Food texture. AVI Westport, Corm.

Ptocharski, W. 1982. Strawberries-quality of fruits, their storage life and suitability for processing-Part 111. Fruit Sci. Rpt. 9(3):11 1122.

Smith, R.B. and A.A. Reyes. 1988. Controlled atmosphere storage of Ontario grown celery. J. Amer. Soc. Hort. Sci. 113(3):390-394.

Voisey, P.W, D.C. MacDonald, M. Kloek, and W. Foster. 1972. The Ottawa texture measuring system. An operational manual. Eng. Res. Serv., Agr. Can., Ottawa. Bul. 7024. 